\title{
Morphometric Differentiation and Asessment of Function of the Fulani and Yoruba Ecotype Indigenous Chickens of Nigeria
}

\author{
Diferenciación Morfométrica y Evaluación de la Función de Ecotipos \\ de Pollos Nativos Fulani y Yoruba de Nigeria \\ Olawunmi, O. O.; Salako, A. E. \& Afuwape, A. A.
}

\begin{abstract}
OLAWUNMI, O. O.; SALAKO, A. E. \& AFUWAPE, A. A. Morphometric differentiation and assessment of function of the Fulani and Yoruba ecotype indigenous chickens of Nigeria. Int. J. Morphol., 26(4):975-980, 2008.

SUMMARY: Data on bodyweight and 11 body measurements were taken on 51 Fulani and 101Yoruba ecotype chicken from two central poultry markets: Ilorin in the middle belt and Ibadan in the southwest region of Nigeria, respectively. The aim was to provide baseline information on size characteristics of Fulani and Yoruba ecotype chickens, differentiate between the types and use the morphometrical variables for a preliminary assessment of type and function. Results showed that least square means of live weight, wing and shank length, body, thigh and toe length, beak length and breast breadth of the Fulani ecotype were generally higher $(\mathrm{P}<0.01)$ than those of the Yoruba ecotype. The males were also superior $(\mathrm{P}<0.01)$ to the females for comb, wing, shank length and breast breadth while live weight, toe and thigh length also differ $(\mathrm{P}<0.05)$ within each ecotype. Thecomb of males was more prominent than those of the females. Coefficients of variation were very small signifying a monotypic condition and an almost equal opportunity of selection for type based on body parameters of the two ecotype chickens. The Fulani ecotype was bigger than the Yoruba ecotype chicken. The significantly longer $(\mathrm{p}<0.05)$ bodies of the Fulani suggests a departure in function between the genotypes. The Fulani chickens appear more closely suited for egg production than the Yoruba type. Their potential for developing a more adapted commercial stock and genetic improvement of the chickens for the region andother implications of type on function are discussed.
\end{abstract}

KEY WORDS: Body size; Yoruba and Fulani chickens; Body measurements; Function.

\section{INTRODUCTION}

Adaptability of indigenous chickens in the tropical environment has been through reduction in body sizes as a means of reducing maintenance feed requirement and increasing feed efficiency (Rashid et al., 2005). This is necessary for them to survive the scavenging feed resource base reportedly inadequate quantitatively and qualitatively (Dana \& Ogle, 2002). Limit is thus placed on the growth and reproductive potential of the indigenous chickens (Kitalyi, 1998), the effect of which is felt in their weight gains and final body weight. Attempts to provide adequate diet has not been economically justifiable (Pedersen, 2002; Lwesya et al., 2004) shifting attention to the genetic improvement of these chickens for effective utilization of dietary nutrients.

Indigenous chickens constitute $80 \%$ of the 120 million poultry found in Nigeria (Fayeye et al., 2006).

The resource is economically important to the people of Nigeria. This is possible because rearing of indigenous chickens demands use of very little resources and brings financial reward in a short while. The Food and Agricultural Organization recognizes these fact and views rural poultry as an important tool for poverty alleviation in Africa.

Study of indigenous chickens is necessary for proper understanding of how to boost production under the prevailing extensive condition and their possible inputs for the development of commercial chicken type.

\section{MATERIALS AND METHOD}

Location. Data was obtained from Fulani and Yoruba ecotype chicken at two poultry markets. The first was Molete in Ibadan for the Yoruba ecotype chicken and the new market in Ilorin for the Fulani ecotype chicken. These locations were selected because they have large concentration of the respective indigenous chicken populations all year round. 
Data collection. Using a $20 \mathrm{~kg}$-weighing instrument and a measuring tape, liveweight and 11 body parameters were taken on 101 Yoruba comprising 52 males and 59 females and 51 Fulani ecotype chicken consisting of 46 males and 5 females. The monitored variables include comb length (CL), beak length (BEL), head length (HL), neck length (NL), body length (BL), wing length (WL), shank length (SL), thigh length (THL), and toe length (TL). Others were breast length (BRL), breast breadth (BRB) and live weight (W). With the help of a field assistant, the birds were each time held in comfortable position and measurements taken in particular order many times for accuracy. Taking the liveweight after body measurements for each bird produced more reliable weight score since the birds were then more settled.

Statistical Analysis. Least square means, standard deviation (SD), standard error (SE) and coefficient of variation (CV $\%$ ) for each body parameters monitored were computed using the SAS (1999) package. These were split on the basis of sex and genotype. T-statistic procedure of the same package was used to detect the significance of the difference between the classes prescribed.

\section{RESULT AND DISCUSSION.}

The unequal sample sizes and sex ratios of the two populations investigated reflect the population structure and the relative abundance of the two types. Interbreeding was completely absent between the populations sampled since more of the times, the Fulani type was isolated far away in the rural suborb where very few females than males were available for investigation. Again, males were generally more frequently put up for sales because they attract higher prices as they are more cherished for use in rituals and during festive periods. On the other hand, only spent females are always put up for sales since they are responsible for more chickens.

Body weight. Descriptive statistics results as presented in table 1 showed that the Fulani chickens were generally bigger in size than the Yoruba type: mean liveweight were $1.76 \pm 0.4 \mathrm{~kg}$ and $0.79 \pm 0.21 \mathrm{~kg}$ for Fulani and Yoruba ecotypes respectively. However, opportunities for genetic improvement of body weight through selection appears higher in the Yoruba ecotype as shown by the respective associated coefficient of variation being $21.6 \%$ against $19.8 \%$ obtained for Fulani ecotype, although the significance of the difference was not tested. Males also had higher values than the females for liveweight and all body parameters measured (Table I). Coefficient of variation of body weight among male Fulani type was much higher than that for females (19.6\% against $8.2 \%)$. Though this difference was not so apparent with the Yoruba type, results suggests that while concentrating on selection for breeding among males could result in genetic improvement in the variety, selection among the females must be used for the Yoruba ecotype.

Body Measurements. The body of the Fulani type is longer: $30.1 \pm 2.5 \mathrm{~cm}$ against $24.00 \pm 1.8 \mathrm{~cm}$ for the Yoruba type. This single measurement confers the superiority for egg laying on Fulani chickens when the body length characteristics of the exotic layers conspecifics are considered. Body length together with head length can indicate potential for egg production. In this investigation, head length of $12.9 \pm 1.64 \mathrm{~cm}$ is also significantly higher than $11.1 \pm 10.7 \mathrm{~cm}$ for the Yoruba ecotype chickens. The coefficient of variation of $98.9 \%$ is even more highly discriminating between the two varieties for head length than for any other variable. The use of beak length in instituting differentiation between the populations is not traditionally strong because at local level, debeaking of varying degrees is still a seldom operation performed to curb pecking and mortality among the birds. However, we still observed that beak length of the Fulani type is still longer: $3.8 \pm 0.4$ against $2.9 \pm 0.4 \mathrm{~cm}$. It is surprising that the neck lengths of the males of both varieties are the same $(9.30 \pm 1.4 \mathrm{~cm}$ and $9.30 \pm 1.6 \mathrm{~cm}$ for the Yoruba and Fulani types, respectively) though associated standard deviation and coefficient of variations as well as the respective figures for the females were different.

Shank and thigh lengths of the Fulani type are longer than those for the Yoruba type. These are the measure of the height of the birds. Since the exotic males that are raised exclusively for meat are rather characteristically taller than their laying counterparts.

Table II presents the t-statistic comparison between the ecotypes within each of the sexes. It shows that the live weight, breastbreadth, toe length, thigh length, shank length, wing length, body length and beak length of the Fulani ecotype were superior $(\mathrm{P}<0.01)$ to those of the Yoruba ecotype chicken.

Comb length of the males were not significantly ( $>>0.05$ ) different being 6.53 and $7.09 \mathrm{~cm}$ for Yoruba and Fulani males and 2.81 and $3.30 \mathrm{~cm}$ long for the females, respectively. Neck length followed the same trend: both males measured $9.30 \mathrm{~cm}$, while the females were 8.33 and 8.84 for Yoruba and Fulani type, respectively. However, while head length of Fulani male is similar to that of Yoruba type male $(12.85$ against $11.06 \mathrm{~cm})$ there was a difference between the same variable for the respective females.(12.50 and $9.02 \mathrm{~cm}$ for the Fulani and Yoruba types, respectively). Observation showed contrary trend for the breast length (BRL): breast length of the females of the two ecotypes were 
OLAWUNMI, O. O.; SALAKO, A. E. \& AFUWAPE, A. A. Morphometric differentiation and assessment of function of the Fulani and Yoruba ecotype indigenous chickens of Nigeria. Int. J. Morphol., 26(4):975-980, 2008.

Table I. Means, standard deviation, standard error and coefficient of variation of measured body parameters of Fulani and Yoruba ecotype chickens.

\begin{tabular}{|c|c|c|c|c|c|c|c|c|c|}
\hline \multirow[b]{2}{*}{ Body parameters } & \multirow[b]{2}{*}{ Sex } & \multicolumn{4}{|c|}{ Yoruba ecotype } & \multicolumn{4}{|c|}{ Fulani Ecotype } \\
\hline & & $\mathbf{C V}$ & Mean & SD & SE & $\mathbf{C V}$ & Mean & SD & SE \\
\hline \multirow[t]{3}{*}{ Comb length } & $\mathrm{M}$ & 29.66 & 6.53 & 2.18 & 0.34 & 33.33 & 7.09 & 2.10 & 0.31 \\
\hline & $\mathrm{F}$ & 18.92 & 2.81 & 0.85 & 0.11 & 30.15 & 3.33 & 0.62 & 0.28 \\
\hline & $\mathrm{T}$ & 34.29 & 4.35 & 2.40 & 0.24 & 55.06 & 6.72 & 2.31 & 0.32 \\
\hline \multirow[t]{3}{*}{ Beak length } & M & 10.83 & 2.97 & 0.35 & 0.05 & 11.82 & 3.81 & 0.41 & 0.06 \\
\hline & $\mathrm{F}$ & 11.78 & 2.82 & 0.51 & 0.07 & 17.93 & 3.52 & 0.41 & 0.19 \\
\hline & $\mathrm{T}$ & 11.05 & 2.88 & 0.45 & 0.04 & 15.68 & 3.78 & 0.42 & 0.05 \\
\hline \multirow[t]{3}{*}{ Head length } & M & 12.76 & 11.06 & 10.96 & 1.69 & 98.86 & 12.85 & 1.64 & 0.24 \\
\hline & $\mathrm{F}$ & 7.13 & 9.02 & 1.21 & 0.16 & 13.40 & 12.50 & 0.89 & 0.40 \\
\hline & $\mathrm{T}$ & 12.32 & 9.90 & 7.15 & 0.71 & 72.20 & 12.81 & 1.58 & 0.22 \\
\hline \multirow[t]{3}{*}{ Neck length } & $\mathrm{M}$ & 17.85 & 9.30 & 1.43 & 0.22 & 15.28 & 9.30 & 1.66 & 0.24 \\
\hline & $\mathrm{F}$ & 6.86 & 8.33 & 1.20 & 0.16 & 14.43 & 8.84 & 0.61 & 0.27 \\
\hline & $\mathrm{T}$ & 17.18 & 8.73 & 1.38 & 0.14 & 15.83 & 9.26 & 1.59 & 0.22 \\
\hline \multirow[t]{3}{*}{ Body length } & $\mathrm{M}$ & 8.45 & 24.00 & 1.97 & 0.30 & 8.19 & 30.05 & 2.54 & 0.37 \\
\hline & $\mathrm{F}$ & 4.11 & 23.31 & 2.46 & 0.32 & 10.55 & 26.92 & 1.11 & 0.50 \\
\hline & $\mathrm{T}$ & 8.76 & 23.60 & 2.28 & 0.23 & 9.67 & 29.74 & 2.60 & 0.36 \\
\hline \multirow[t]{3}{*}{ Wing length } & $\mathrm{M}$ & 8.57 & 18.62 & 1.54 & 0.24 & 8.26 & 23.08 & 1.98 & 0.29 \\
\hline & $\mathrm{F}$ & 12.47 & 16.67 & 1.58 & 0.21 & 9.43 & 20.34 & 2.54 & 1.13 \\
\hline & $\mathrm{T}$ & 9.52 & 17.48 & 1.83 & 0.18 & 10.46 & 22.81 & 2.17 & 0.30 \\
\hline \multirow[t]{3}{*}{ Shank length } & M & 8.19 & 31.18 & 1.59 & 0.24 & 5.09 & 38.33 & 3.14 & 0.46 \\
\hline & $\mathrm{F}$ & 11.86 & 26.74 & 1.61 & 0.21 & 5.37 & 32.50 & 3.85 & 1.74 \\
\hline & $\mathrm{T}$ & 9.59 & 28.59 & 2.71 & 0.27 & 6.03 & 37.76 & 3.62 & 0.51 \\
\hline \multirow[t]{3}{*}{ Thigh length } & M & 9.98 & 18.27 & 0.98 & 0.15 & 9.49 & 22.03 & 2.20 & 0.32 \\
\hline & $\mathrm{F}$ & 6.63 & 15.80 & 1.08 & 0.14 & 5.86 & 19.62 & 1.30 & 0.58 \\
\hline & $\mathrm{T}$ & 10.27 & 16.83 & 1.61 & 0.16 & 9.54 & 21.79 & 2.24 & 0.31 \\
\hline \multirow[t]{3}{*}{ Toe length } & $\mathrm{M}$ & 13.61 & 6.42 & 0.55 & 0.08 & 8.51 & 7.67 & 1.04 & 0.15 \\
\hline & $\mathrm{F}$ & 12.43 & 5.68 & 0.71 & 0.09 & 12.37 & 6.62 & 0.82 & 0.37 \\
\hline & $\mathrm{T}$ & 14.07 & 5.99 & 0.74 & 0.07 & 12.32 & 7.57 & 1.07 & 0.15 \\
\hline \multirow[t]{3}{*}{ Breast length } & $\mathrm{M}$ & 32.02 & 8.38 & 7.75 & 0.31 & 23.98 & 10.70 & 3.43 & 0.51 \\
\hline & $\mathrm{F}$ & 8.62 & 8.01 & 2.01 & 0.21 & 20.76 & 7.94 & 0.68 & 0.31 \\
\hline & $\mathrm{T}$ & 32.21 & 1.61 & 1.80 & 0.18 & 22.92 & 10.43 & 3.36 & 0.47 \\
\hline \multirow[t]{3}{*}{ Breast breadth } & $\mathrm{M}$ & 4.52 & 1.88 & 0.29 & 8.20 & 27.85 & 2.57 & 0.38 & 9.23 \\
\hline & $\mathrm{F}$ & 9.62 & 22.01 & 1.88 & 0.24 & 8.52 & 24.58 & 1.11 & 0.50 \\
\hline & $\mathrm{T}$ & 22.94 & 22.40 & 1.93 & 0.19 & 8.60 & 27.53 & 2.65 & 0.37 \\
\hline \multirow[t]{3}{*}{ Body weight } & $\mathrm{M}$ & 19.56 & 1.01 & 0.18 & 0.03 & 17.01 & 1.79 & 0.35 & 0.05 \\
\hline & $\mathrm{F}$ & 8.18 & 0.92 & 0.22 & 0.03 & 23.80 & 1.46 & 0.12 & 0.05 \\
\hline & $\mathrm{T}$ & 19.82 & 0.97 & 0.21 & 0.02 & 21.59 & 1.76 & 0.35 & 0.05 \\
\hline
\end{tabular}

(Yoruba ecotype: $\mathrm{M}=52, \mathrm{~F}=59$ ) (Fulani ecotype: $\mathrm{M}=46, \mathrm{~F}=5$ ); $\mathrm{M}=$ Males; $\mathrm{F}=$ Females; $\mathrm{SD}=$ Standard deviation; $\mathrm{SE}=\mathrm{Standard}$ error; $\mathrm{CV}=$ Coefficient of variation; $\mathrm{T}=$ Total.

similar $(7.75$ and $7.94 \mathrm{~cm})$ but there was a difference between the males (10.69 against $8.38 \mathrm{~cm})$. As previously observed, the breast measurement is a useful indicator for meatiness.
Breast breadth has been reported to be a good indicator of meatiness in most poultry species. (Adebambo et al., 1996; Fayeye et al.). Observation here suggests that the value of 
the Fulani type as cockerel is higher. All other variables appeared to have discriminant value within the sexes between the ecotypes as revealed by the significant t-values.

The comb and neck length of the two ecotype chickens were not statistically different $(\mathrm{P}>0.05)$ from each other. The breast length of the Fulani ecotype male was longer $(\mathrm{P}<0.01)$ than that of the Yoruba ecotype male. However, breast length of the Fulani and Yoruba ecotype females were not statistically different $(\mathrm{P}>0.05)$. Table II also show that the beak of the Fulani was longer $(\mathrm{P}<0.01)$ than those of the Yoruba ecotype chicken.

Table III shows that values obtained for the comb, wing and shank length along with the breastbreadth of the males were higher $(\mathrm{P}<0.01)$ than those of the females in the two ecotypes.

Table II. Differences between body parameters of Yoruba and Fulani ecotype chickens within sexes.

\begin{tabular}{|c|c|c|c|c|c|}
\hline \multicolumn{2}{|l|}{ Sex } & \multicolumn{2}{|c|}{ Male } & \multicolumn{2}{|c|}{ Female } \\
\hline Variables & ETP & Mean & Prob $>t$ & Mean & Prob $>t$ \\
\hline \multirow[t]{2}{*}{$\mathrm{CL}$} & Yor & $6.53 \pm 2.18$ & $\mathrm{~ns}$ & $2.81 \pm 0.85$ & $\mathrm{~ns}$ \\
\hline & Ful & $7.09 \pm 2.10$ & & $3.30 \pm 0.62$ & \\
\hline \multirow[t]{2}{*}{ BEL } & Yor & $2.97 \pm 0.35$ & $* *$ & $2.81 \pm 0.41$ & $* *$ \\
\hline & Ful & $3.81 \pm 0.51$ & & $2.51 \pm 0.41$ & \\
\hline \multirow[t]{2}{*}{ HL } & Yor & $11.06 \pm 10.96$ & $\mathrm{~ns}$ & $9.02 \pm 1.21$ & $* *$ \\
\hline & Ful & $12.85 \pm 1.64$ & & $12.50 \pm 0.89$ & \\
\hline \multirow[t]{2}{*}{ NL } & Yor & $9.30 \pm 1.43$ & $\mathrm{~ns}$ & $8.33 \pm 1.20$ & $\mathrm{~ns}$ \\
\hline & Ful & $9.30 \pm 1.66$ & & $8.84 \pm 0.61$ & \\
\hline \multirow[t]{2}{*}{$\mathrm{BL}$} & Yor & $24.00 \pm 1.97$ & $* *$ & $23.31 \pm 2.46$ & $* *$ \\
\hline & Ful & $30.05 \pm 2.54$ & & $26.92 \pm 1.11$ & \\
\hline \multirow[t]{2}{*}{ WL } & Yor & $18.62 \pm 1.54$ & $* *$ & $16.67 \pm 1.58$ & $* *$ \\
\hline & Ful & $30.05 \pm 1.98$ & & $20.34 \pm 2.54$ & \\
\hline \multirow[t]{2}{*}{ SL } & Yor & $31.18 \pm 1.59$ & $* *$ & $26.74 \pm 1.61$ & $* *$ \\
\hline & Ful & $38.33 \pm 3.51$ & & $32.50 \pm 3.85$ & \\
\hline \multirow[t]{2}{*}{ THL } & Yor & $18.27 \pm 0.98$ & $* *$ & $15.80 \pm 1.08$ & $* *$ \\
\hline & Ful & $22.03 \pm 2.20$ & & $19.62 \pm 1.30$ & \\
\hline \multirow[t]{2}{*}{$\mathrm{TL}$} & Yor & $6.42 \pm 0.55$ & $* *$ & $15.80 \pm 1.74$ & $* *$ \\
\hline & Ful & $7.67 \pm 0.71$ & & $6.62 \pm 0.82$ & \\
\hline \multirow[t]{2}{*}{ BRL } & Yor & $8.38 \pm 2.01$ & $* *$ & $7.75 \pm 3.43$ & $\mathrm{~ns}$ \\
\hline & Ful & $10.69 \pm 1.69$ & & $7.94 \pm 0.68$ & \\
\hline \multirow[t]{2}{*}{ BRB } & Yor & $22.94 \pm 1.88$ & $* *$ & $22.01 \pm 1.88$ & $* *$ \\
\hline & Ful & $27.85 \pm 2.57$ & & $24.58 \pm 1.11$ & \\
\hline \multirow[t]{2}{*}{ LW } & Yor & $1.04 \pm 0.18$ & $* *$ & $0.92 \pm 0.22$ & $* *$ \\
\hline & Ful & $1.79 \pm 0.35$ & & $1.46 \pm 0.12$ & \\
\hline
\end{tabular}

$* \quad=\mathrm{P} \leq 0.05 \quad \mathrm{ETP}=$ Ecotypes

$* *=\mathrm{P} \leq 0.01 \quad$ Yor $=$ Yoruba ecotype chicken $($ Male $=42 ;$ Female=59)

$\mathrm{ns}=\mathrm{P}>0.05 \quad$ Ful $=$ Fulani ecotype $\operatorname{chicken}($ Male $=46 ;$ Female $=5)$
Table III shows that least square means of liveweight, toe and thigh lengths of the Yoruba ecotype males were longer $(\mathrm{P}<0.01)$ than those of the females, while the liveweight, toe and thigh length of the Fulani ecotype males also differ $(\mathrm{P}<0.05)$ from those of the females.

Differences $(\mathrm{P}<0.01)$ also exists between the body length of the male and female Fulani ecotype chickens while none $(\mathrm{P}>0.05)$ existed between the sexes of the Yoruba ecotype chicken (Table III).The breast and beak length of male and females within ecotype was not statistically different $(\mathrm{P}>0.05)$ (Table III).

The longer bodies of the Fulani chicken mean longer bones than the Yoruba ecotype which will also add to the overall mass of the chicken. This supports earlier report Attey (1999) that the Fulani ecotype is heavier than other Nigerian indigenous chickens. The superiority of the Fulani over the Yoruba ecotype for most body measurements especially breast breadth also suggests that the dimensions are more associated with muscling and meatiness.

The smaller stature of the Yoruba ecotype chickens appears adaptive. This may mean that its continued existence in the tropics was made possibly by continued reductions (Yeasmin \& Howlider, 1998; Broady et al., 1984) in live weight and body sizes than the Fulani ecotype over a long period of time. This agrees with the report of Badubi et al. (2006) that the environment iscrucial in the phenotypic appearance of individual chickens in the tropics. Abdul-Rahman (1989) and Horst (1988) had earlier reported that body size and bodyweight are important in the adaptation of chickens in the tropics. Smaller body sizes is said to be important to reduce maintenance feed requirements and increase feed efficiency in the tropics. This is necessary for survival in the free range system because of scarce feed resources and the uncertainty surrounding feed supply. 
Table III. Differences between the sexes for body parameters within each ecotype chickens.

\begin{tabular}{|c|c|c|c|c|c|}
\hline \multicolumn{2}{|l|}{ Ecotype } & \multicolumn{2}{|c|}{ Yoruba } & \multicolumn{2}{|c|}{ Fulani } \\
\hline V ariables & Sex & Mean & Prob > & Mean & Prob > \\
\hline \multirow[t]{2}{*}{$\mathrm{CL}$} & $\mathrm{M}$ & $6.53 \pm 2.18$ & $* *$ & $7.09 \pm 2.10$ & $* *$ \\
\hline & F & $2.81 \pm 0.85$ & & $3.30 \pm 0.62$ & \\
\hline \multirow[t]{2}{*}{ BEL } & $\mathrm{M}$ & $2.97 \pm 0.35$ & $\mathrm{~ns}$ & $3.81 \pm 0.51$ & $\mathrm{~ns}$ \\
\hline & $\mathrm{F}$ & $2.81 \pm 0.41$ & & $2.51 \pm 0.41$ & \\
\hline \multirow[t]{2}{*}{$\mathrm{HL}$} & M & $11.06 \pm 10.96$ & $\mathrm{~ns}$ & $12.85 \pm 1.64$ & $\mathrm{~ns}$ \\
\hline & $\mathrm{F}$ & $9.02 \pm 1.21$ & & $12.50 \pm 0.89$ & \\
\hline \multirow[t]{2}{*}{ NL } & M & $9.30 \pm 1.43$ & $* *$ & $9.30 \pm 1.66$ & $\mathrm{~ns}$ \\
\hline & $\mathrm{F}$ & $8.33 \pm 1.20$ & & $8.84 \pm 0.61$ & \\
\hline \multirow[t]{2}{*}{ BL } & M & $24.00 \pm 1.97$ & $\mathrm{~ns}$ & $30.05 \pm 2.54$ & $* *$ \\
\hline & $\mathrm{F}$ & $23.31 \pm 2.46$ & & $26.92 \pm 1.11$ & \\
\hline \multirow[t]{2}{*}{ WL } & M & $18.62 \pm 1.54$ & $* *$ & $16.67 \pm 1.58$ & $* *$ \\
\hline & $\mathrm{F}$ & $16.67 \pm 0.21$ & & $20.34 \pm 2.54$ & \\
\hline \multirow[t]{2}{*}{ SL } & M & $31.18 \pm 1.59$ & $* *$ & $38.33 \pm 3.51$ & $* *$ \\
\hline & $\mathrm{F}$ & $26.74 \pm 1.61$ & & $32.50 \pm 3.85$ & \\
\hline \multirow[t]{2}{*}{ THL } & M & $18.27 \pm 0.98$ & $* *$ & $22.03 \pm 2.20$ & $*$ \\
\hline & $\mathrm{F}$ & $15.80 \pm 1.08$ & & $19.62 \pm 1.30$ & \\
\hline \multirow[t]{2}{*}{$\mathrm{TL}$} & M & $6.42 \pm 0.55$ & $* *$ & $7.67 \pm 0.71$ & $*$ \\
\hline & $\mathrm{F}$ & $15.80 \pm 1.74$ & & $6.62 \pm 0.82$ & \\
\hline \multirow[t]{2}{*}{ BRL } & M & $8.38 \pm 2.01$ & ns & $10.69 \pm 1.69$ & $\mathrm{~ns}$ \\
\hline & $\mathrm{F}$ & $7.75 \pm 3.43$ & & $7.94 \pm 0.68$ & \\
\hline \multirow[t]{2}{*}{$\mathrm{BRB}$} & M & $22.94 \pm 1.88$ & $* *$ & $27.85 \pm 2.57$ & $* *$ \\
\hline & $\mathrm{F}$ & $22.01 \pm 1.88$ & & $24.58 \pm 1.11$ & \\
\hline \multirow[t]{2}{*}{$\mathrm{W}$} & $\mathrm{M}$ & $1.04 \pm 0.18$ & $* *$ & $1.79 \pm 0.35$ & $*$ \\
\hline & $\mathrm{F}$ & $0.92 \pm 0.22$ & & $1.46 \pm 0.12$ & \\
\hline
\end{tabular}

establishes avaerage differences between these ecotype chickens from the morphological point of view. They have been subjected to the same stress factors yet differ in size and dimensions. These suggest that genetic programme to improve indigenous chickens (or utilize them in breeding programmes) should be based on individual evaluation of each ecotype. The adaptive nature of the size is probably responsible for the continued existence of the ecotypes in their respective habitats.

OLAWUNMI, O. O.; SALAKO, A. E. \& AFUWAPE, A. A. Diferenciación morfométrica y evaluación de la función de ecotipos de pollos nativos Fulani y Yoruba de Nigeria. Int. $\boldsymbol{J}$. Morphol., 26(4):975-980, 2008.

RESUMEN: Los datos sobre peso corporal y 11 mediciones corporales se hicieron en 51 pollos ecotipo Fulani y 101 pollos ecotipo Yoruba de dos mercados centrales de aves de corral: de Llorin en el Centro y de Ibadan en la región Sudoeste de Nigeria, respectivamente. El objetivo fue propor-

$$
\begin{array}{rlrl}
* & =\mathrm{P} \leq 0.05 & & \text { Yor }=\text { Yoruba ecotype chickens }(\mathrm{M}=42: \mathrm{F}=59) \\
* * & =\mathrm{P} \leq 0.01 & & \text { Ful }=\text { Fulani ecotype chickens }(\mathrm{M}=46: \mathrm{F}=5) \\
\mathrm{ns} & =\mathrm{P}>0.05 & \mathrm{~F} \quad=\text { Female } \mathrm{M}=\text { Male }
\end{array}
$$

Tables II and III shows more differences between sexes of the Yoruba ecotype than those of the Fulani ecotype chickens for live weight, thigh and toe length. Longer body length of the Fulani distinguishes them from the Yoruba ecotype while longer $(\mathrm{P}<0.01)$ comb length will help in identifying the males from the females in any population of the two ecotype chickens. Result obtained for breast length shows differences $(\mathrm{P}<0.01)$ only between the males emphasizing the importance of the males in the inheritance of body size of the Fulani ecotype chicken.

\section{CONCLUSION}

The Fulani ecotype chicken has longer body sizes and is heavier than the Yoruba ecotype chicken as differentiated in the study by the zoometrical parts. This study however cionar información básica sobre las características de tamaño de los pollos ecotipos Fulani y Yoruba, diferenciar entre los tipos y el uso de variables morfométricas para una evaluación preliminar del tipo y función. Los resultados mostraron que las medias de peso vivo, longitud de ala y patas, cuerpo, muslos y pies, largo del pico y ancho del pecho del ecotipo Fulani fueron en general mayores $(\mathrm{P}<0,01)$ que las del ecotipo Yoruba. Los machos también fueron mayores ( $\mathrm{P}$ $<0,01)$ a las hembras en la longitud de la cresta y ala, largo de la pata $\mathrm{y}$ ancho de pecho, mientras que el peso vivo, longitud del dedo del pie y el muslo también fueron diferentes $(\mathrm{P}<0,05)$ dentro de cada ecotipo. La cresta de los machos fue más prominente que las de hembras. Los coeficientes de variación fueron muy pequeños, lo que significa una condición monotípica y una similitud de oportunidades de selección para el tipo, basada en parámetros corporales. El ecotipo Fulani fue más grande que Yoruba. El significativo mayor cuerpo $(\mathrm{P}<0,05)$ del Fulani sugiere una salida en función entre los genotipos. El pollo Fulani parece más adecuado para la producción de huevos que el tipo Yoruba. Su potencial para el desarrollo de un stock comercial más adaptado y la mejora genética de los pollos de la región y otras implicancias del tipo función se discuten.

PALABRAS CLAVE: Tamaño del cuerpo; Pollos Yoruba y Fulani; Mediciones corporales; Función. 


\section{REFERENCES}

Abdul-Rahman, A. E. Significance of some major genes in relation to the productive adaptability of four German sub lines compared with local Egyptian chickens under Assiut subtropical condition. Assuit University, Egypt, 1989.

Adebambo, O. A.; Ikeobi, C. O. N.; Ozoje, M. O.; Adenowo, J. A. \& Osinowo, O. A. Variation in qualitative traits and their effects on the performance of local ducks and Turkeys. Nigeria. J. Gen., 11:20-3, 1996.

Attey, J. O. Rural Poultry Production in Western middle belt of Nigeria. In: Sonaiya, E. B. (Editor). Rural Poultry in Africa. Proceedings of an International workshop held in Ile- Ife, Nigeria, 1999.

Badubi, S. S.; Rakereng, M. \& Marumo, M. Morphological characteristics and feed resources available for indigenous chickens in Botswana. Livest. Res. Rural Dev. 18(1), 2006. Disponible en. http://www.cipav.org.co/lrrd/ lrrd18/1/badu18003.htm.

Broady T. B.; Siegel, P. B. \& Cherry, J. A. Age, body weight and body composition requirement for the onset of sexual maturity of dwarf and normal chickens. Br. Poultry Sci., 25:245-52, 1984.

Dana, N. A. \& Ogle, B. Effects of Scavenging on Diet Selection and Performance of Rhodes Island Red and Fayoumi Breeds of Chicken offered a Choice of Energy and or Protein feeds. Trop. Anim. Health Prod., 34:41729, 2002.

Kitalyi, A. J. Village Chicken Production Systems in Rural Africa Household Food Security and Gender Issues. FAO, Rome, 1998.

Fayeye, T. R.; Ayorinde, K. L.; Ojo, V. \& Adesina, O. M. Frequency and influence of some major genes on body weight and body size parameters of Nigerian local chickens. Livestock Res. Rural Dev., 18(3):37, 2006.

Horst, P. Native Pool as Resources for Genome and Major Gene with Direct and Indirect Effect on Productive Adaptability. Proceedings XVIII World Poultry Congress, Nagoya, Japan, 1998.

Lwesya, H.; Phoya, R. K. D.; Safalaoh, A. C. L. \& Gongwe, T. N. P. Rearing chicks in enclosures under village conditions: effect on chick growth and reproductive per- formance of mother hens. Livestock Res. Rural Dev., 16(89), 2004. Disponible en: http://www.cipav.org.Irrd/ Irrd116/11/we361089.htm.

Pedersen, C. V. Production of Semi Scavenging Chickens in Zimbabwe. PhD Thesis, Royal Veterinary and Agricultural University, Copenhagen, Denmark, 2002.

Rashid, M. A.; Howlider, M. A. R.; Alam, J.; Rashid, A.; Kawar, M. H. \& Azmal, S. A. Effect of dwarfism on Reproductive and Meat yield parameters of Crossbred Chicken. International J. of Poultry Sci., 4(6):372-7, 2005.

SAS, Statistical Analysis System. User Guide. Cary, North Carolina, U.S.A., 1999.

Yeasmin, T. \& Howlider, M. A. R. Comparative physical features, egg production and egg quality characteristics of normal and dwarf indigenous (Deshi) hens of Bangladesh. J. Appl. Anim. Res., 13:191-6, 1998.

Correspondence to:

A.E. Salako

Genetics Laboratory

Department of Animal Science

University of Ibadan, Ibadan.

NIGERIA

Email: aesalak@yahoo.com

Received: 04-10-2007

Accepted: 14-08-2008 